\title{
The Effects of Growth in the Agricultural and Service Sectors on Out-Of-School Children in the Lao PDR
}

\author{
Viriyasack Sisouphanthong ${ }^{1}$, Terukazu Suruga ${ }^{2}$ \\ ${ }^{1}$ National University of Laos, Lao People's Democratic Republic \\ ${ }^{2}$ Kobe University, Japan \\ Correspondence: Viriyasack Sisouphanthong, National University of Laos, Lao People's Democratic Republic.
}

Received: March 30, 2020

doi:10.11114/ijsss.v8i3.4792
Available online: April 29, 2020

URL: https://doi.org/10.11114/ijsss.v8i3.4792

\begin{abstract}
Lao PDR experienced a high rate of out of school children in the last decade, while its economy grew averaging 6.96\% from 1989 until 2017. A high growth in certain economic sectors (e.g., agriculture or services) may inadvertently induce students to leave school to work directly, and also indirectly encourage them to leave school to replace adult labor in the household. The current research targets to examine the impact of the growth of the sectors on out-of-school children in primary and lower secondary education. The analysis uses household data from 2012 and employs a multinomial logit model. The results suggest that the growth in the agricultural and service sectors reduces the possibility of school-age children in school enrollment. Moreover, it increases the probability of never enrolled and school dropout.
\end{abstract}

Keynote: Out-of-school children, school dropout, economic growth, Lao PDR, multinomial logit

\section{Introduction}

Growth of a nation's economy generally increases the number of jobs and income. More jobs and higher wage levels increase household income and economic resources which are believed to increase the support of school enrollment and the student performance of children (Mariara and Mwabu, 2007; Kim and Sherraden, 2011; and Nam and Huang, 2009). Therefore, the growth is supposed to lower a number of out-of-school children. However, researchers point out that growth of certain economic sectors is a possible determinant of increasing child work, and subsequently pulling children out of school. A study of Swaminathan (1998) suggests that India experienced increasing child labor in various fast- growing regions of the country. The rising number of child workers was also found at the beginning of industrialization of the United Kingdom (Haywood, 1988). When jobs available are in sectors which require unskilled labor (e.g., as agriculture and basic services), households could directly ask children to work for extra income. Additionally, household might indirectly encourage children to help with the farm or to take care of some family members at home when parents are away for jobs (Kak, 2004; Kambhampati \& Rajan, 2006). Moreover, although some of these children also study while they are working, there is a high chance that they will drop out of school. Stopping going to school for even a brief period often leads to permanent school dropout (UCW, 2010; Adamssie, 2003; McNeal, 1997).

Lao PDR had a high GDP growth in recent years: from 1989 to 2017 the economy grew by $6.96 \%$ annually (World Bank, 2017). Also, it was one of the countries with the highest rate of out-of-school children and school dropouts in the East Asia Pacific region. The Understanding Children's Work program showed a significant number of out-of-school children among South East Asian countries (UCW, 2014). Lao PDR had a high out-of-school rate of $11.6 \%$ of children aged 7 to 14 and $12.3 \%$ of children aged 10 to 14 . Additionally, many out of school children are involved in labor activity, either in the formal or informal sector. The percentage of female child workers is higher than male child workers by $8.7 \%$ to $6.7 \%$ respectively. Rural areas had a higher percentage of working children (9.2\%) compared to urban area (2.2\%). A cumulative dropout rate to the last grade of primary education was $26.6 \%$, and to last grade of lower secondary education was $25.1 \%$. Child worker is generally employed in unskilled activities. Indeed, most child worker is involved in agricultural work (95.4\%).

Previous studies have focused on the impact of the economic growth on increasing child labor; however, it is rare to see studies that focus on the effects of the growth of agricultural and service sectors on out-of-school children. The research question that this study aims to answer is "to what extent is the effect of the growth of agricultural and service sectors 
on out-of-school children?" The objective is to evaluate the impact of the growth on a probability of children to be enrolling in school, dropout of school, and never enrolled in school. A quantitative approach is employed. The Lao household survey in 2012 is used with the multinomial logit equation.

After this section, the literature review is in Section 2. An analytical framework and econometric specification are explained in Section 3. Section 4 is a description of the data. Section 5 discusses the findings and Section 6 concludes the research.

\section{Literature Review}

The direct impact of economic growth on out-of-school children is caused by increased child work. The factors influencing child work can be divided into demand and supply sides. The demand side comes from the labor market, while the supply side is the result of a variety of household economic conditions, school service, etc. Thus, economic growth can influence both supply and demand factors.

The economy growth enhances businesses to expand production, which increase the use of capital and labor. The businesses prefer to hire cheaper labor to minimize cost of production, and if the task is for unskilled workers, children become a possibility. Heywood (1988) concluded that there is a significant increase in child labor during the industrialization. However, since adults also participate and earn more, the incidence of child labor eventually declines in later periods of economic development, as evidenced also in Europe (Horrell \& Humphries, 1995). Swaminathan (1998) showed increasing child labor in the fast growing regions of India. Kambhampati \& Rajan (2006) also investigate the effect of employment growth on child labor in India. They found that while a higher level of average village wages and regional domestic production decreases child labor, a higher share of agricultural production increases the probability of child labor. When the benefits of available jobs and income increases, the opportunity cost of schooling for children also increases. As the opportunity cost increases, children from poor households are likely to drop out of school and go to work either on the farm or in the home. Poverty is a major factor that drives child labor (Basu \& Van, 1998). In addition, the high cost of schooling lowers the likelihood of children enrolling in school, particularly children from poor households (Kitaura, 2009; Hunt, 2008; Hammond, Linton, Smink, \& Drew, 2007). Moreover, students are more likely to drop out of school if it is difficult to access a school, due to such factors as traveling long distances with poor road conditions (Hunt, 2008).

The indirect effect of economic growth is when children substitute for adult labor, for example, when children drop out of school to take over household works from adults (Kak, 2004). When there are available jobs in the formal sector (e.g., places like factories), adults are more likely to take the jobs rather than children (Bhalotra \& Heady, 2003; Lieten, 2002). Furthermore, parents who have their own businesses are more likely to make their children work for them (Edmonds, Truk, Glewwe, Agrawal, \& Dollar, 2004).

Moreover, there are a number of determinants on schooling status. Parents' education is one of the most important factors. Higher educated parents are more likely to enroll and keep their children in school (Tansel, 2002; Binder, 1998; Blanden \& Gregg, 2004; Qian \& Smyth, 2011; Knight \& Shi, 1996). Likewise, the household's economic resources and income play a significant role in sponsoring children's education. Increasing household income rises the education budget, which consequently increases the possibility of enrollment (Mariara \& Mwabu, 2007; Kim \& Sherraden, 2011; Nam \& Huang, 2009; Binder, 1998; Blanden \& Gregg, 2004; Qian \& Smyth, 2011; Glewwe \& Jacoby, 2003). Furthermore, the number of sibling decreases the potential of children to enroll in school because a child must share a common resource for education with sibling (Connelly \& Zheng, 2003).

\section{Methodology}

\subsection{Analytical Framework}

A household's decision to send a child to school is dependent on non-economic (e.g., cultural) and economic factors, foremost of which likely are the expected return from the child's human capital and the direct and indirect cost of schooling. From a study by Gertler \& Glewwe (1990), the expected household utility conditional on a decision to enroll a child to school is as:

$$
U_{1}=U\left(S_{1}, C_{1}\right)+\varepsilon_{1}
$$

where $S_{1}$ is an increment human capital of the child from another year of schooling, $C_{1}$ is a consumption possible after incurring of the cost of schooling. The cost of schooling includes both direct costs (school tuition fee, transportation, etc.) and indirect costs (e.g., forgone possible income from child labor when the child is in school). $\varepsilon$ is a random taste shifter. In the opposite case, the expected utility of household, which does not send the child to school would be:

$$
U_{0}=U\left(C_{0}\right)+\varepsilon_{0}
$$


where $C_{0}$ is the consumption possible without incurring the cost of schooling. The budget constraint of the expected utility function is

$$
C_{1}+P=C_{0}=Y
$$

where $P$ is the total cost for sending the child to school and $Y$ is a total household disposable income. From equation (1) and (2), the unconditional utility maximization problem is as

$$
U^{*}=\max \left(U_{0}, U_{1}\right)
$$

where $U^{*}$ is the maximized utility. From the maximization problem, if the expected utility for sending the child to school is higher than the expected utility of not sending the child to school, then household would keep the child in school. And when the expected utility of not sending the child to school is greater than the utility of sending the child to school, the household therefore would keep the child out of school (Gertler \& Glewwe, 1990).

The growth of the economic sectors that require unskilled labor increases the indirect costs, which is the forgone income for sending the child to school and substituted labor for household work. When the indirect cost increases, the expected utility of not sending the child to school is likely to exceed the expected utility of sending the child to school. Therefore, the child is dropped from school or never enrolled.

\subsection{Econometric Equation}

For utility maximization, households must select whether to send a child to school or not. In discrete choice analysis, if one alternative is chosen, then the utility is maximized. The relevant factors that influence the probability of selecting the alternatives are stated in an econometric equation below:

$$
P(S S)=f(F e m a l e, \text { Lao, HHHeduc, HHincome, HHchild, P-income, } P \text {-agri, } P \text {-service })
$$

where $S S$ is a multiple choice outcome that indicates schooling status of children who have school aged of 6 to 14 years old. This school age refers to compulsory education of primary and lower secondary. The children are categorized into three groups which are school enrolling, never enrolled, and school dropout. The schooling enrolling group refers to in-school children, while the never enrolled and school dropout refers to out-of-school children. As mentioned earlier, the effect of employment growth can be direct and/or indirect on out-of-school children; thus, the dependent variable specifies children who are in or out of school, regardless of whether they are working. Table 1 shows the definition and measurement of variables in the equation (5). The dependent variables are a categorical outcome, thus it is estimated by the multinomial logit model (the maximum likelihood estimation). In the multinomial logit, the probability of individual $i$ to select alternative $j$ is as:

$$
p_{i j}=\frac{\exp \left(\mathrm{x}^{\prime} \beta_{j}\right)}{\sum_{k=1}^{m} \exp \left(\mathrm{x}_{i}^{\prime} \beta_{k}\right)}, \quad j=1, \ldots, m
$$

where $\mathrm{x}_{i}$ are characteristics of respondents and $\beta_{j}$ are coefficients. The model indicate that $p_{i j}$ is between zero to one. The coefficients are also transformed into an average marginal effect for simple interpretation.

Table 1. Definition of Variables

\begin{tabular}{ll}
\hline Variables & Measurement \\
\hline Dependent variables & \\
\hline SS & 1 = school enrolling, 2 = never enrolled, 3 = school dropout \\
\hline Independent variables \\
\hline Female & $1=$ female, $0=$ otherwise. \\
Lao & $1=$ Lao ethnic children, $0=$ otherwise. \\
HHHeduc & Education year of head of household. \\
HHincome & Logarithm form of household expenditure per capita. \\
HHchild & Number of school aged children per household. \\
$P$-income & Logarithm form of estimated provincial GDP \\
$P$-agri & Logarithm form of provincial rice product. \\
$P$-service & Logarithm form of provincial service building. \\
\hline
\end{tabular}


Female children are expected to have higher probability to be out of school; while ethnic majority children (Lao ethnicity) are hypothesized to have a lower possibility to be out of school. HHHeducation, HHincome, and HHchild variables are the head of household's education, household income level, and the number of school aged children in a household, respectively. They are used to control household socioeconomic status. HHHeducation is expected to have a negative effect on the out-of-school status because a highly educated head-of-household seems to understand the importance of education and support a child's education. HHincome is supposed to reduce the probability of being out of school, because when household income increases, the educational budget is expected to increase. In practice, household expenditure per capita is used as a proxy for the income. An increasing number of school aged children in household (HHchild) is hypothesized to increase a probability of being out of school. Naturally, households face budget constraints in sending children to school.

P-income is the provincial general income level, $P$-agriculture is the provincial agricultural production level, and $P$-service is the provincial service production level. $P$-income represents a provincial development level. It is expected to reduce the number of out-of-school children. On the other hand, P-agriculture and $P$-service represent the demand for unskilled labor; thus, when the production of both sectors grows, there is a higher likelihood of children being out of school. Unfortunately, there is no precise published data of the provincial income and sectorial production levels. Therefore, a proxy variable for P-income is a provincial consumption level. Annual rice production is the proxy for the agricultural production (P-agriculture), because rice is a main food in Lao PDR which has a high share in agricultural production. $P$-service is a stock of buildings for service business. An increase in the number of buildings for service business potentially show an expansion in service production.

\section{Data}

The unit of analysis is an individual level of children from 6 to 14 years old (primary to lower secondary education ages). The sample is from the household survey, the Lao Expenditure and Consumption Survey 2012 (LECS5). This is the largest household survey available recently, and was conducted by the Lao Statistics Bureau. The provincial level indicators are from the 2012 statistic year book. Out of the total sample in LECS5 (44,447 individuals), there have 5,997 samples after data cleaning. The data description of variables is shown in Table 2. The school enrolling group shares were $87.6 \%$, while those never-enrolled and school dropout groups share of $8 \%$ and $4.4 \%$ respectively. The female sample size is about half of the total sample (49.5\%), and Lao ethnicity children make up $42.5 \%$. The average education year of head of household is 3.984 years, and the average number of children per household is 3.114 persons.

Table 2. Data description

\begin{tabular}{lll}
\hline Variable & Mean & SD \\
\hline SS = 1 (school enrolling) & 0.876 & 0.345 \\
SS 2 (never enrolled) & 0.080 & 0.286 \\
SS $=3$ (dropout) & 0.044 & 0.213 \\
Female & 0.495 & 0.500 \\
Lao & 0.425 & 0.493 \\
HHHeduc & 3.984 & 4.111 \\
HHincome & 11.040 & 1.693 \\
HHchild & 3.114 & 1.521 \\
P-income & 19.746 & 0.927 \\
P-agri & 4.808 & 0.990 \\
P-service & 5.158 & 0.733 \\
\hline
\end{tabular}

\section{Results and Discussion}

Table 3 shows the result of determinants on schooling status. There are three columns of three schooling status. The coefficients are not yet transformed to a marginal effect, thus we can interpret a sign and statistically significant. The school enrolling status is used as the reference group, thus there is no illustration of its coefficients. 
Table 3. Results of Multinomial Logit Estimation

\begin{tabular}{|c|c|c|c|}
\hline & $\begin{array}{l}\text { (1) } \\
\text { Enrolling } \\
\text { (Base outcome) }\end{array}$ & $\begin{array}{l}\text { (2) } \\
\text { Never-enrolled }\end{array}$ & $\begin{array}{l}\text { (3) } \\
\text { Dropout }\end{array}$ \\
\hline Female & & $\begin{array}{l}0.053 \\
(0.769)\end{array}$ & $\begin{array}{l}0.153^{*} \\
(1.917)\end{array}$ \\
\hline Lao & & $\begin{array}{l}-0.749^{* * * *} \\
(-8.015)\end{array}$ & $\begin{array}{l}-0.021 \\
(-0.203)\end{array}$ \\
\hline HHHeducation & & $\begin{array}{l}-0.100 * * * \\
(-8.261)\end{array}$ & $\begin{array}{l}-0.087 * * * \\
(-6.208)\end{array}$ \\
\hline HHincome & & $\begin{array}{l}-0.066 * * * \\
(-2.989)\end{array}$ & $\begin{array}{l}-0.059^{* *} \\
(-2.379)\end{array}$ \\
\hline HHchild & & $\begin{array}{l}0.040^{*} \\
(1.716)\end{array}$ & $\begin{array}{l}0.054 * * \\
(2.001)\end{array}$ \\
\hline P-income & & $\begin{array}{l}-0.490 * * * \\
(-5.606)\end{array}$ & $\begin{array}{l}-0.506^{* * * *} \\
(-5.095)\end{array}$ \\
\hline$P$-agriculture & & $\begin{array}{l}0.474 * * * * \\
(8.040)\end{array}$ & $\begin{array}{l}0.465 * * * \\
(6.802)\end{array}$ \\
\hline$P$-service & & $\begin{array}{l}0.115^{*} \\
(1.534)\end{array}$ & $\begin{array}{l}0.227 * * \\
(2.482)\end{array}$ \\
\hline Constant & & $\begin{array}{l}5.993 * * * \\
(4.586)\end{array}$ & $\begin{array}{l}4.971 * * * \\
(3.416)\end{array}$ \\
\hline $\begin{array}{l}\text { Observations } \\
\text { Log likelihood }\end{array}$ & \multicolumn{3}{|c|}{$\begin{array}{l}5,997 \\
-2547\end{array}$} \\
\hline
\end{tabular}

Overall, number of determinants have an expected outcome. A sign of each variable is consistent in both never-enrolled and school dropout. This shows that the effect of all the determinants has similar impacts on either outcome, or in other words on out-of-school status. Many variables are statistically significant.

The Female variable has a positive sign in both never-enrolled and school dropout, but it is only statistically significant in the school dropout. This means that there is no difference in never-enrolled between genders, but female children have a higher probability of dropping out of school compared to male children. The variable Lao has a negative sign in both columns, but it is statistically significant at $1 \%$ in never-enrolled status. The negative sign suggests that Lao ethnic children have a lower possibility to be in the never-enrolled status compared to non-Lao ethnic children.

The head of household education (HHHeducation) shows a negative sign and is statistically significant at $1 \%$ for both never-enrolled and dropout categories. The result is consistent with previous studies (Tansel, 2002; Binder, 1998; Blanden \& Gregg, 2004; Qian \& Smyth, 2011; Knight \& Shi, 1996) which showed an important role of parents' education on stopping children from leaving school. Parents with higher education generally understand the benefits of education and want to support their child in their education. For another household characteristic, the household income also illustrates a negative effect and is statistically significant in both never-enrolled and school dropout. It confirms the effect from several studies (Mariara \& Mwabu, 2007; Kim \& Sherraden, 2011; Nam \& Huang, 2009; Blinder, 1998; Blanden \& Gregg, 2004; Qian \& Smyth, 2011; Glewwe \& Jacoby, 2003). A household with higher economic resources provides more educational support to its child. Further, the effect of the number of children per household is positive in both out-of-school statuses, and statistically significant at $10 \%$ in a never-enrolled and $5 \%$ in school dropout. An increasing number of children per household increases the cost of education (an economic constraint), which continues to lower the possibility of children attending school. This result is similar to those from a study by Connelly \& Zheng (2003).

On the provincial variable, provincial income shows a negative effect on a never-enrolled and school dropout. It is statistically significant at $1 \%$. The richer province could support education development more than other provinces. Increasing provincial income, firstly, increases household economic resources which in turn support children's education, and secondly, provides a better infrastructure for schools which consequently reduces out-of-school rate.

On the other hand, growth in the agricultural and service sectors have a positive effect on never-enrolled and dropout students. The results confirm several previous studies on the effect of growth on out-of-school (see Kambhampati \& Rajan, 2006; Heywood, 1988; Horrell \& Humphries, 1995; Swaminathan, 1998). The variable of P-agriculture has a positive sign and is statistically significant at $1 \%$ in every column. As expected, it suggests that a growth of agricultural production increases the use of child work directly as additional farm labor, and indirectly as supplement labor in the household. It consequently increases the probability of children to be out of school. Furthermore, the growth in the service sector also reduces the probability of children attending school. Its effect is positive for both never-enrolled and 
school dropout, and statistically significant. Higher growth in the service industry increases the number of job vacancies where children could work. Therefore, it can draw children from school.

Table 4 shows the average marginal effect of the determinants on the schooling status. The interpretation of the coefficient is the likelihood of children to be school enrolling, never-enrolled, and dropout. Only the effect with a statistically significance of at least $10 \%$ is used for interpretation.

Table 3. Marginal Effect from Multinomial Logit Estimation

\begin{tabular}{llll}
\hline & $(1)$ & $(2)$ & $(3)$ \\
& Enrolling & Never enroll & Dropout \\
\hline Female & $-0.012^{*}$ & 0.004 & $0.008^{*}$ \\
Lao & $0.053^{* * *}$ & $-0.058^{* * *}$ & 0.005 \\
HHHeducation & $0.013^{* * *}$ & $-0.008^{* * * *}$ & $-0.004^{* * *}$ \\
HHincome & $0.008^{* * *}$ & $-0.005^{* * *}$ & $-0.003^{* *}$ \\
HHchild & $-0.006^{* *}$ & $0.003^{*}$ & $0.003^{*}$ \\
$P$-income & $0.061^{* * *}$ & $-0.035^{* * *}$ & $-0.025^{* * *}$ \\
$P$-agriculture & $-0.056^{* * *}$ & $0.033^{* * *}$ & $0.023^{* * *}$ \\
$P$-service & $-0.020^{* * *}$ & 0.008 & $0.011^{* *}$ \\
\hline
\end{tabular}

Note: Reported parameters are in average marginal effect and ${ }^{* * *} \mathrm{p}<0.01,{ }^{* *} \mathrm{p}<0.05,{ }^{*} \mathrm{p}<0.1$.

First, female children are less likely to be enroll in school by $1.2 \%$ and more likely to be dropout by $0.8 \%$ compared to male children. There is no statistically difference among gender in the never-enrolled. Lao ethnic children are more likely to enroll in school by $5.3 \%$, and they are less likely to never-enrolled by $5.8 \%$.

Increasing one year of the head of household education leads to $1.3 \%$ higher chance of children in school enrolling, $0.8 \%$ lower in never-enrolled, and $0.4 \%$ lower in dropout. Likewise, the effect of household income on school enrollment is positive, and to never-enrolled and dropout is negative. If the household income increases by $1 \%$, it would approximately increase the possibility of enrolling by $0.008 \%$, decrease the likelihood to never-enrolled by $0.005 \%$ and to dropout by $0.003 \%$. In addition, a household with one more child of schooling age decreases the probability to enroll by $0.6 \%$, and increases a possibility to never-enrolled and dropout by $0.3 \%$.

The growth in provincial income by $1 \%$ increases the probability of enroll by $0.061 \%$, while it reduces the propensity to never-enroll by $0.035 \%$ and to dropout by $0.025 \%$, approximately. The growth in agricultural production by $1 \%$ reduces the possibility of enrolling by about $0.056 \%$, and increases the possibility of never-enroll and dropout by $0.033 \%$ and $0.023 \%$ respectively. Finally, the growth in the services sector reduces the chance of children to be in the school by about $0.021 \%$ and increases the opportunity to drop out from school by $0.011 \%$ approximately.

\section{Conclusion}

Out-of-school children are a major problem worldwide. Lao PDR also face a high rate of out-of-school children. One of the most important factors that drives children out of school is the growth of particular economic sectors such as agriculture and service. As the sectors growth, business expands production and increases demand for labor. When there is demand for unskilled labor, children might directly drop out of school to work; or, indirectly stay out of school to substitute adult labor on family farms and/or to take care of family members.

This study employed Lao household data from 2012 and used a multinomial logit model to estimate the effect of the growth on out-of-school children. The unit of analysis is the individual child level. The dependent variable is the category outcome which refers to school enrolling, never-enrolled, and school dropout. The control variables are children's gender and ethnicity, head of household education, household income level, and the number of children in a household. The interested variables are provincial income level, provincial agricultural production, and provincial service production.

In general, the results suggest that a higher level of provincial income can increase the probability of school enrollment and reduce the possibility of never enrolled and dropout. In contrast, the growth of the agricultural sector can pull children out of school and reduce the propensity of school enrollment. Similarly, growth in the service sector increases the school dropout and reduces the probability of children entering school. 
The results provide important public policy implications. They show that growth in economic sectors such as agriculture and services can increase the number of out-of-school children. Thus, the government should be concerned in regions with large increases in agricultural and service production. School support programs should be provided to school in those regions. Also, it is important to encourage households to keep their children in school.

A future study should be considered examining other economic sectors that could potentially increase the number of out-of-school children. Also, future research could seek for precise measurements of provincial level indicators. Also, it should be concerned with the effect of the growth on other education development variables such as the quality of education.

\section{References}

Admassie, A. (2003). Child labour and schooling in the context of a subsistence rural economy: can they be compatible? International Journal of Educational Development, 23(2), 167-185. https://doi.org/10.1016/S0738-0593(02)00012-3

Basu , K., \& Van, P. H. (1998). The economics of child labor. American economic review, 412-427.

Bhalotra, S., \& Heady, C. (2003). Child farm labor: The wealth paradox. The World Bank Economic Review, 17(2), 197-227. https://doi.org/10.1093/wber/lhg017

Binder, M. (1998). Family Background, Gender and Schooling in Mexico. Journal of Development Economics, 35, 54-71. https://doi.org/10.1080/00220389808422564

Blanden, J., \& Gregg, P. (2004). Family Income and Educational Attainment: A Review of Approaches and Evidence for Britain. Oxford Review of Economic Policy, 20, 245-263. https://doi.org/10.1093/oxrep/grh014

Connelly, R., \& Z. Zheng. (2003). Determinants of School Enrolment and Completion of 10 to 18 year olds in China. Economics of Education Review, 22, 379-388. https://doi.org/10.1016/S0272-7757(02)00058-4

Edmonds, E., Turk, C., Glewwe, P., Agrawal, N., \& Dollar, D. (2004). Economic Growth, Poverty and Household Welfare in Viet Nam, 505-550.

Gertler, P., \& Glewwe, P. (1990). The willingness to pay for education in developing countries: Evidence from rural Peru. Journal of Public Economics, 42(3), 251-275. https://doi.org/10.1016/0047-2727(90)90017-C

Glewwe, P., \& Jacoby, H. (2003). Economic Growth and the Demand for Education: Is there a Wealth Effect? Journal of Development Economics, 74(1), 33-51. https://doi.org/10.1016/j.jdeveco.2003.12.003

Hammond, C., Linton, D., Smink, J., \& Drew, S. (2007). Dropout risk factors and exemplary programs: A technical report. National Dropout Prevention Center/Network (NDPC/N).

Heywood, C. (2002). Childhood in nineteenth-century France: work, health and education among the'classes populaires'. Cambridge University Press.

Horrell, S., \& Humphries, J. (1995). The Exploitation of Little Children": Child Labor and the Family Economy in the Industrial Revolution. Explorations in Economic History, 32(4), 485-516. https://doi.org/10.1006/exeh.1995.1021

Hunt, F. (2008). Dropping out from school: A cross-country review of literature." CREATE Pathways to Access No 16. Consortium for Research on Educational Access, Transitions and Equity: University of Sussex.

Kak, S. (2004). Magnitude and profile of child labour in the 1990s: evidence from the NSS data. Social Scientist, 43-73. https://doi.org/10.2307/3518327

Kambhampati, U. S., \& Rajan, R. (2006). Economic growth: A panacea for child labor? World Development, 34(3), 426-445. https://doi.org/10.1016/j.worlddev.2005.08.010

Kim, Y., \& Sherraden, M. (2011). Do parental assets matter for children's educational attainment? Evidence from mediation tests. Children and Youth Services Review, 33(6), 969-979. https://doi.org/10.1016/j.childyouth.2011.01.003

Kitaura, K. (2009). Child labor, education aid, and economic growth. Journal of Macroeconomics, 31(4), 614-620. https://doi.org/10.1016/j.jmacro.2009.02.004

Knight, J., \& Shi, L. (1996). Educational Attainment and the Rural-Urban Divide in China. Oxford Bulletin of Economics and Statistics, 58, 83-117. https://doi.org/10.1111/j.1468-0084.1996.mp58001005.x

Lieten, G. K. (2002). Child labour in India: disentangling essence and solutions. Economic and political Weekly, 5190-5195.

Mariara, K., J., \& Mwabu, D. K. (2007). Determinants of school enrollment and education attainment: Empirical evidence 
from Kenya1. South African Journal of Economics, 75(3), 572-593. https://doi.org/10.1111/j.1813-6982.2007.00138.x

McNeal Jr, R. B. (1997). Are students being pulled out of high school? The effect of adolescent employment on dropping out. Sociology of Education, 206-220. https://doi.org/10.2307/2673209

Nam, Y., \& Huang, J. (2009). Equal opportunity for all? Parental economic resources and children's educational achievement. Children and Youth Services Review, 31(6), 625-634. https://doi.org/10.1016/j.childyouth.2008.12.002

National Statistics Bureau. (2013). Statistics Year Book 2012. Vientiane Capital, Lao PDR.

Qian, J. X., \& Smyth, R. (2011). Educational expenditure in urban China: income effects, family characteristics and the demand for domestic and overseas education. Applied Economics, 43(24), 3379-3394. https://doi.org/10.1080/00036841003636292

Swaminathan, M. (1998). Economic growth and the persistence of child labor: Evidence from an Indian city. World Development, 26(8), 1513-1528. https://doi.org/10.1016/S0305-750X(98)00063-1

Tansel, A. (2002). Determinants of school attainment of boys and girls in Turkey: individual, household and community factors. Economics of education review, 21(5), 455-470. https://doi.org/10.1016/S0272-7757(01)00028-0

Understanding Children's Work (UCW). (2010). Child labour: trends, challenges and policy responses. Joining forces against child labour. UCW Working Paper. Geneva: ILO.

Understanding Children's Work (UCW). (2014). Understanding children's work and youth employment outcomes in Lao $P D R$. Country Report. UCW Programme, Rome.

\section{Copyrights}

Copyright for this article is retained by the author(s), with first publication rights granted to the journal.

This is an open-access article distributed under the terms and conditions of the Creative Commons Attribution license which permits unrestricted use, distribution, and reproduction in any medium, provided the original work is properly cited. 